\title{
Pandemic Corona Virus and Policy of Forest Resources Conservation
}

\author{
Aries Isnandar ${ }^{1}$, Absori $^{2}$, Harun $^{3}$, Natangsa Surbakti ${ }^{4}$ \\ ${ }^{1}$ Doctoral Student of Faculty of Law, Universitas Muhammadiyah Surakarta, ${ }^{2}$ Professor, Universitas \\ Muhammadiyah Surakarta, ${ }^{3}$ Professor of Law, Universitas Muhammadiyah Surakarta, \\ ${ }^{4}$ Lecturer of Faculty of Law, Universitas Muhammadiyah Surakarta
}

\begin{abstract}
These brief highlights some of the identified and perceived impacts of the COVID-19 crisis on development aspects interconnected with the forest sector, with a particular emphasis on the impacts on the production and trade of forest workers. It proposes a series of recommendations as a basis for policy development in the aftermath of the crisis, and highlights potential opportunities to leverage the progress achieved so far, to ensure that decades of advances are not reversed. Forest products, including non-wood forest products continue to support livelihoods throughout the crisis while delivering essential items, such as hygiene and sanitary products, biomass for heating, ethanol forsanitizer, respirator paper and packaging for parcels. Forest preservation is currently a concern of many countries, including Indonesia, Basic policies are needed so that the problem of forest destruction can be overcome. Furthermore, in order to achieve the objectives of forestry policy, there are several conditions after pandemic Covid 19 outbreaks, one of which is that there must be an active involvement in conserving forest resources.
\end{abstract}

Keywords: Policy, forest preservation, Covid 19, pandemic.

\section{Introduction}

Pandemics are hazards related to large-scale outbreaks of infectious diseases that can greatly increase morbidity and mortality over a wide geographic area and cause significant economic, social,and political disruption. The consequences of a pandemic, affecting people on a worldwide scale, with expected longterm impacts and consequences on the coupled socioecological systems,can be described as a disaster. On 13 March 2020, the World Health Organization (WHO) declared the novel coronavirus disease (COVID-19) a pandemic pushing humankind into an ongoing global crisis, which is unique in the recent history, at least by its spatial extent, rapid onset and its complexity of consequences. ${ }^{1}$

\section{Corresponding Author:}

\section{Aries Isnandar}

Budi Utomo Street, Ponorogo

e-mail: isnandarumpo@gmail.com
Based on observations conducted by the researcher, in the conservation area of natural resources in Wonogiri, located in Gendol hill forest nature reserve in Dali Village, Geneng Village and Conto Village, Bulukerto Sub-District, Wonogiri Regency, which is located exactly at the foothill, there are 650 families in these villages that are very dependent on the existence of clean water from the Gendol Hill river, as said by Sadiman in a conversation (December 2017). In other areas, approximately $20 \mathrm{~km}$ to the south-west side, there is Donoloyo teak forest, Watusumo Village, Slogohimo Sub-District, Wonogiri Regency, which covers 8300 $\mathrm{m}^{2}$ area. According to the provision, that area must be preserved and maintained in harmony and balance, taking into account the preservation of the ecosystem, said Totok a Forest Ranger, Person in Charge of BKSDA Wonogiri (May 2017).

Ministerial Regulation of Environment and Forestry of the Republic of Indonesia Number P.6/Menlhk/ Setjen/ot 1.0/1/2016 concerning Organization and Work Procedure of Forest Area Stabilization Center 
and Law No. 5 of 1990 concerning Conservation of Biological Natural Resources and their Ecosystems are the provisions that provide a basis for ideas in general which has to be adjusted with the actual condition, said Hidayat, W (May 2018), Secretary of the Wonogiri Environmental Office.

Sadiman said that "if I have helped the community including the government, does the government intend to pay attention to my wishes?" Sadiman himself wants the area to become a tourism area that will later be monitored and maintained. This also includes sedimentation condition that occurs in Gajah Mungkur Wonogiri Reservoir and not-maintained Donoloyo teak forest, Watusumo Village, Slogohimo Sub-District, Wonogiri Regency, which until now require attention from the government, especially concrete maintenance follow-up plans, which of course must be preceded by development-oriented policies, which are mainly based on local wisdom, as stated by Bintoro, T, an activist and an observer of forestry (October 2019).

Besides that, the researcher tried to meet with policy makers who in this case were responsible informants namely Mr. Edi Santoso (Deputy Regent of Wonogiri) said that there are 2 forms of conservation policy currently running after the pandemic in Wonogiri namely forests within the area and forests outside the area. If we talk about forests in the area I can say one hundred percent has nothing to do with the Wonogiri Regency government policy, because the management of conservation issues, and production management, etc. are all the authority or authority of Perhutani. For those outside the area or community forest (forest on community-owned land) the Wonogiri Regency government has the authority to determine policies. Teak Forest Donoloyo including Alas Gendol is fully the authority of Perhutani (forest within the area). The regional government of Wonogiri Regency in accordance with the regional autonomy law number 23 of 2014 in its policy does not include forests in the area which means that even though its geographical location is still within the Wonogiri regency area, the regional government of Wonogiri Regency is not entitled to forest policies in the area.

Based on the aforementioned description, the Policy of Forest Resources Conservation after the Covid 19 outbreak needs tobereviewed in order to comprehensively understand the overview of conservation towards forest resources in Wonogiri Regency area.

\section{Method}

This research uses normative and empirical research method. As a result, the observations conducted are in accordance with the required needs. ${ }^{2}$

\section{Results and Discussion}

a. Definition of Policy: The term policy as referred herein is equated with the word policy which is distinguished from policy (wisdom) and policy (virtue). Winarno ${ }^{3,4}$ and $\mathrm{Wahab}^{5}$ agree that the term 'policy' is often used interchangeably with other terms such as goals, programs and grand design. For policymakers and people engaged in the field of policy, the use of these terms may be confusing.

Basically, there are many restrictions or definitions regarding the meaning of policy. Each of these definitions gives different emphasis. This difference arises because every expert has different backgrounds.

A writer said that policy is the principle or way of acting chosen to direct decision making. ${ }^{4,6}$ According to Ealau and Kenneth Prewitt quoted by Charles O. Jones, policy is a standing decision characterized by behavioral consistency and repetitiveness on the part of both those who make it and those who abide it. $^{7}$ The United Nations (UN) states that a definition of policy is a guide for action. This guideline can be very simple or complex, general or specific, broad or narrow, vague or clear, loose or detailed, qualitative or quantitative, public or private. Policy with this definition may be in the form of a declaration about a program, regarding certain activities or plans. ${ }^{5}$

Based on the discussion above, we intend to formulate a definition of public policy as a response to a political system, through government power, towards the problems of society. In other words, public policy is the government's decision to solve public problems. Such decision can implied actions or not actions, the word "public" can mean both community and company, it can also mean the statepolitical system and administration. Meanwhile, "government" is a person or group of people who are mandated by all members of a political system to make arrangements for the entire system, It can be $\mathrm{RT}, \mathrm{RW}$, village, regency, province, State, between countries (ASEAN, EU) and the world (WTO, UN). 
b. Power manifestation of community influence in its care for forest conservation and resources: In the first research, based on observations and involved directly into the field conducted by the writer by using the methodology of sociological approach about the forestry conservation after pandemic Covid 19 outbreak, the overview of resources conservation that have been carried out apparently is not as expected.

The second research was located in Donoloyo teak forest, Watusumo Village, Slogohimo SubDistrict, Wonogiri Regency, which covers an area of $8300 \mathrm{~m}^{2}$. According to the provision, that area must be preserved and maintained in harmony and balance, taking into account the sustainability of the ecosystem. The forest is historically a forest that is located on the banks of the upper reaches of Bengawan Solo.

The covid 19 outbreak benefits the conservation and natural resources agency (Balai Konservasi dan Sumber Daya Alam, BKSDA) and until now, the forest has been preserved since people will not dare to take the slightest element related to the teak trees because of the pandemic. From the description above, it turns out that the forest ranger as well as the head of BKSDA can take advantage of this situation so that the forest rangers can internally make a policy that can be used in the context of awareness to the surrounding community for the maintenance of the Conservation and Natural Resources Agency (BKSDA).

c. Bottom up policy model before the pandemic outbreak: Policy implementation is an activity that can be seen after the issuance of valid direction from a policy that includes efforts to manage inputs in order to produce outputs or outcomes for the community. The stage of policy implementation can be characterized and distinguished from the policy making stage. Policy making on one hand is a process that has a bottom-up logic, in the sense that the policy process begins with the delivery of aspirations, requests or support from the society. On the other hand, policy implementation has a top-down logic, in the sense of decreasing abstract or macro alternatives policy into concrete or micro actions. ${ }^{8}$ Grindle stated that implementation is a general process of administrative action that can be examined at a particular program level. ${ }^{9}$ Meanwhile, Van Meter and Van Horn stated that policy implementation is an action carried out by the government and private sector both individually and in groups with the intention of achieving purposes. Grindle added that the implementation process will only being when concrete goals and objectives have been determined, an activity program has been arranged and funds are ready and submitted in order to achieve the goals. ${ }^{10}$

d. Typology of policy resolution: In this research, the writer must obtain the overview of the conservation of forest resources in the Wonogiri Regency area in accordance with the researched object. It is done in order to obtain a typology of each researched area, as the resolution of problems arising from each of researched area is not the same. Based on the aforementioned matter, in accordance with the arising problems, the forestry policies should change for the better. The policy enforcers should consider giving incentives to the affected people.

The work of the forest apparatus is lighter because the forest looting perpetrators are scared of the pandemic, thus the condition of the forest is more maintained. The policy makers should apply the health protocol in making policies. Complete a workplace risk assessment including, creating a day-to-day plan that follows the guidelines Develop a COVID-19 Infection Prevention and Control Protocol (Protocol) based on the risk assessment on the forestry policy. Implement and enforce the Protocol to help prevent and control the transmission of COVID-19. Reducing the number of social interactions between state apparatus in the forestry and people and nearby communities. Physical distancing or enhancing protection via masks where physical distancing is not practical Good hygiene practices on forest inspection. Cleaning and disinfecting high touch point areas at the start and end of each day

From the aforementioned events, the Forest Ranger and the head of BKSDA, Totok, can take advantage of the occurring situation and condition so that the story can be used as materials for awareness to the community for the preservation of BKSDA during pandemic, this kind of policy model must be heard and considered by related officials from the local to the center in order to be used as a reference material in the framework of determined policy during pandemic. 
Therefore, if we compare the costs incurred with the benefits in the sense there is neither profit nor loss from it. However, if the reservoir is functioned as its original function, then the cost is very high and it seems impossible to be conducted seeing our current economic condition. Also, with regards to green belts planted, apparently it was not carried out in accordance with the protocols during pandemic. This matter must be heard by the concerned officials from the local to the center to be used as materials in determining actions in making policy.

From the problem that arises as the research object, which is regarding the matter of policy decided by the government, in this case the Ministry of Environment, it is still not aspirational. This can be proven by the case of Forest Conservation both in terms of its management or the rights and obligations of each party between the community and the government as occurred in several places.

\section{Conclusion}

Firstly, we must optimize the pandemic gave a security sense in the forest. BKSDA need to give autonomy in addressing environmental issues that are related to policies that favor the community during pandemic by using the potential strengths of local communities and combining them with the strength of interest groups in the community in order to carry out communication to provide data that is true and can be accounted for in order for it to be used as consideration by relevant officials in making policies related to forest resources. Secondly, by using the health protocols during implementation of the policy in the field that occurs and a human relation approach that is combined with the sociological process occurring in public life, by way of emphasizing the formal and logical approach, so that it tends be creative and rejects the routine logic regulations, this is where the enlightenment policy lies on safety of the people and the forest.

\section{Conflict of Interest: No}

\section{Source of Funding: Author}

Ethical Clearance: Yes, From Universitas Muhammadiyah Ponorogo

\section{References}

1. Madhav N, Oppenheim B, Gallivan $\mathrm{M}$, Mulembakani P, Rubin E, Wolfe N. Pandemics: risks, impacts, and mitigation. In: The World Bank. Disease control priorities: improving health and reducing poverty, 3rd ed. Washington, DC, USA: The International Bank for Reconstruction and Development, The World Bank, 2017.

2. Sugiyono. Metodepenelitianpendidikanpendekatankuantitatif, kualitatif, dan R \& D (Educational research method of quantitative, qualitative, and $\mathrm{R}$ \& D approaches. Bandung: Alfabeta, 2010.

3. Winarno B. Teori dan proses kebijakanpublik (Theory and process of public policy). Yogyakarta: Media Press, 2005.

4. Suharno, Dasar-dasarkebijakanpublik (Fundamentals of public policy). Yogyakarta: Ombak Publisher, 2013.

5. Wahab SA. Analisiskebijaksanaan: dariformulasikeimplementasikebijaksaan negara (Policy analysis: from formulation to implementation of state policy). Jakarta: BumiAksara, 2004, p. 1-2.

6. Suharto E. Analisiskebijaksanaanpublik (Analysis of public policy). Bandung: Alfa Beta, 2005. p. 7.

7. O'Jones C. An introduction to the study of public policy. Belmont, CA: Wadswort, 1970.

8. Wibawa S. Evaluasikebijakanpublik (Public policy evaluation). Jakarta: PT Raja Grafindo Persada, 1994.

9. Grindle $\mathrm{M}$, editor. Politics and a policy implementation in the third world. New Jersey: Prince town University Press, 1980.

10. Ratu Agung 78 [Internet]. 2010. Implementasikebijakan bottom up dan campuran (Bottom up and mixed policy implementation). Available from: http://ratuagung78.blogspot. com/2010/02/implementation-kebyek-bottom-updan.html 